\title{
Efficacy of a novel ferrocenyl diaryl butene citrate compound as a biocide for preventing healthcare- associated infections
}

Mehdi El Arbi, ${ }^{* a b}$ Karim Jalléli, ${ }^{b}$ Fatma Trigui, ${ }^{b}$ Pascal Pigeon, ${ }^{\text {c,d }}$ Meral Görmen, ${ }^{\text {d }}$ Siden Top, Sami Aifa, ${ }^{\text {bsmail Fliss, }}$ ' Gérard Jaouen, ${ }^{* c, d}$ and Riadh Hammami ${ }^{* e}$

${ }^{a}$ Institut Supérieur de Biotechnologie de Sfax, Route de Sokra km 4, BP 261, 3000 Sfax, Université de Sfax, Tunisia

${ }^{b}$ Centre of Biotechnology of Sfax (Sfax University). Route de Sidi Mansour Km 6, BP 1177, 3018 Sfax, Tunisia

${ }^{c}$ Université Pierre et Marie Curie-Paris, Sorbonne Universités, Institut Parisien de Chimie Moléculaire (IPCM) - UMR 8232, 4 place Jussieu, 75252 Paris Cedex 05, France

${ }^{d}$ Chimie ParisTech, Ecole Nationale Supérieure de Chimie de Paris, 11 rue Pierre et Marie Curie, Paris F75231 Paris cedex 05, France

${ }^{e}$ Institute of Nutrition and Functional Foods, Université Laval, G1V OA6 Québec, QC, Canada

Correspondence: mehdi_arbi@yahoo.fror gerard.jaouen@chimie-paristech.fr or riadh.hammami@fsaa.ulaval.ca 


\begin{abstract}
The antiseptic and disinfectant potential of a formulation containing the tamoxifen analogue 1,1bis[4-(3-dimethylaminopropoxy)phenyl]-2-ferrocenyl-but-1-ene citrate was assessed according to European standards and pharmacopeia in comparison with a commercial antiseptic product containing hexamidine diisethionate, chlorhexidine digluconate and chlorocresol as active ingredients. The formulation met the phase 1 requirement of reducing by 5 cycles the counts of microorganisms frequently involved in healthcare-associated infections, namely Escherichia coli ATCC 10536, Pseudomonas aeruginosa ATCC 15442, Staphylococcus aureus ATCC 6538, Enterococcus hirae ATCC 10541 and Candida albicans ATCC 10231. It also killed a clinical isolate of Acinetobacter baumannii highly resistant to antibiotics and antiseptics. In Phase 2/step 2 tests, it reduced counts of E. coli ATCC 10536 by $4 \log$ cycles within 60 seconds on hands (standard EN 1499). The novel formula is a potent biocide, and this demonstration could lead to the development of a new commercial antiseptic.
\end{abstract}

Keywords: $\quad$ organometallic; tamoxifen; 1,1-bis[4-(3-dimethylaminopropoxy)phenyl]-2ferrocenyl-but-1-ene citrate; antiseptic; disinfectant; European standards 


\section{Introduction}

Healthcare-associated infections (HAIs) continue to be a major public health concern worldwide due to the associated morbidity, mortality, non-negligent costs and emergence of multi-resistant bacteria. According to a recent survey in the USA, approximately one of every 25 acute-care inpatients develops at least one HAI, which led to 75,000 fatalities in $2011 .{ }^{1}$ According the European Centre for Disease Prevention and Control (ECDC), 7.1\% of European inpatients were diagnosed with HAI. ${ }^{2}$ In 2013, the most common types of HAIs in Europe were respiratory tract infections (33.6\%), symptomatic urinary tract infections (22.3\%), and skin infections $(21.4 \%){ }^{3}$ The most common bacterial nosocomial infections are due to Escherichia coli (23\%), Staphylococcus aureus (20\%), Pseudomonas aeruginosa (11\%), and Enterococcus spp (6\%). Antibiotic resistance is acquired usually in association with excessive and inappropriate usage (unnecessary prescriptions, inadequate doses and/or treatment time, etc.). HAIs increase the danger of multi-resistant bacteria emerging from routine antibiotic therapy, which is becoming more and more dependent on continuous screening for new antibacterial agents. The use of detergents and disinfectants in hospitals is being intensified due to the discovery of new infectious agents (HIV, hepatitis viruses, prions...) and the necessity of stopping HAIs.

According to the European Committee for Standardization, an antiseptic is defined as a "substance or preparation allowing the treatment of living tissues by killing and/or inhibiting bacteria, fungi or spores and/or inactivating viruses in order to prevent or limit the danger of infection for these tissues" (CEN/TC 216: Chemical Disinfectant and Antiseptic standards). Products suitable for application to healthy skin are henceforth labeled as disinfectants. Antiseptics belong to many chemical families, including quaternary ammonia, chlorhexidine, phenolics, salicylanilides and carbanilides, alcohols, aldehydes (formaldehyde, glutaraldehyde) 
and glyoxal, oxidizers (halogens and derivatives, peroxide), organic acids, organometallics and colorants. ${ }^{4}$ Some disinfectants also belong to these families (chlorinated derivatives, quaternary ammonia, etc.), but are usually aldehydes, in particular formaldehyde. ${ }^{5}$ In Europe, the normative evaluation of antiseptics is based on bactericidal standards EN 1040, EN 13727, and possibly fungicidal standards such as EN 1275, except in the case of hand-washing products, for which only bactericidal and antiviral standards are considered (EN 1499 and EN 1500, EN 14476). ${ }^{6}$ An antiseptic product candidate must first have demonstrated efficacy against bacteria and fungi in phase 1 tests. Its antimicrobial efficacy is then examined under representative conditions in the presence of interfering substances (phase 2/step 1). Finally, phase 2/step 2 tests include assays mimicking conditions of actual use.

Organometallic compounds, which are defined as metal-organic complexes containing at least one direct covalent metal-carbon bond, offer interesting opportunities for the design of novel classes of biocides. ${ }^{7}$ These metal-carbon bonds can exert major electronic and steric effects and thus offer a novel approach to designing medicinal compounds, based on mechanisms differing substantially from those of purely organic molecules. ${ }^{7}$ For example, the ferrocenyl derivative of chloroquine, a ferroquine antimalarial candidate, has been found ten times more active than the parent compound against chloroquine-resistant Plasmodium falciparum. ${ }^{8}$ Similarly, we have synthesized previously a series of ferrocenyl analogues of tamoxifen with anti-proliferative and antimicrobial effects. ${ }^{9,}{ }^{10}$ Broad-spectrum activity combined with low hemolytic activity was observed for 1,1-bis[4-(3-dimethylaminopropoxy)phenyl]-2-ferrocenyl-but-1-ene citrate (compound 1). ${ }^{11}$ In the present work, we report the development of a new biocide based on this compound and our assessment of its antiseptic efficacy according to European standards. A liquid 
formulation containing the new molecule was compared to a commercial biocide in terms of effectiveness against various healthcare-associated microorganisms.

\section{Materials and methods}

\subsection{Chemical compounds and antiseptic formulation}

The compound 1,1-bis[4-(3-dimethylaminopropoxy)phenyl]-2-ferrocenyl-but-1-ene citrate (1)

was synthesized as described previously. ${ }^{10}$ Its structure is represented in Figure 1 . The commercial antiseptic solution $\mathrm{Cytéal}^{\circledR}$, which contains hexamidine diisethionate (2), chlorhexidine digluconate (3) and chlorocresol (4), was used for comparison (Table 1). Our disinfectant formulation contained compound (1) plus the same concentrations of cocamidopropyl betaine, edetic acid and coprah diethanolamide as in the commercial product.

\subsection{Microbial strains and culture conditions}

Escherichia coli ATCC 10536, Pseudomonas aeruginosa ATCC 15442, Staphylococcus aureus ATCC 6538, Enterococcus hirae ATCC 10541, Candida albicans ATCC 10231 and Acinetobacter baumannii (clinical isolate) were grown aerobically in LB broth (Lennox, Difco Laboratories, Sparks, MD, USA) at $37^{\circ} \mathrm{C}$. The microbial strains were sub-cultured at least three times in this medium before use.

\subsection{Antimicrobial activity}

Compound (1) was dissolved in water, doxycycline was dissolved in DMSO, and inhibitory concentrations thereof were assessed using polystyrene micro-assay plates (96-well Microtest,

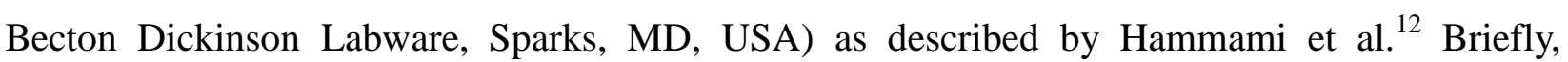
microplates loaded with two-fold serial dilutions of each sample (starting at $254 \mu \mathrm{M}$ ) were seeded with log-phase culture of target strain diluted in LB. The microplates were then incubated at $37^{\circ} \mathrm{C}$ for $24 \mathrm{~h}$ and absorbance at $620 \mathrm{~nm}$ was measured using an Infinite $^{\circledR}$ F200 PRO 
spectrophotometer (Tecan US Inc., Durham, NC, USA). The inhibitory activity of the tested compounds was calculated using the formula:

$$
\mathrm{IA}(\%)=100 \times\left(1-\frac{O D x-O D i}{O D c-O D i}\right)
$$

Where $i$ is the value of the negative control, $c$ is the value of microbial culture without inhibitor, and $x$ is the value of microbial culture containing the test compound.

The antimicrobial activity of compound (1) alone and in formulation was compared at a concentration of $300 \mu \mathrm{g} \mathrm{mL} \mathrm{m}^{-1}$ to that of $\mathrm{Cytéal}^{\circledR}$ (a commercial analogue) using Staphylococcus aureus ATCC 6538 in agar well diffusion tests as described by Hammami et al. ${ }^{12}$

\subsection{Antiseptic assay}

The antiseptic and disinfectant effects of the compound (1) formulation were measured in accordance with European standards EN 1040, EN 13727 and EN 1499. ${ }^{13-15}$ For compliance with EN 1040 and EN 13727, we prepared the microbial suspensions in contact with the tested disinfectant, then filtered and washed the filters to remove the active substance for incubation $\left(37^{\circ} \mathrm{C}\right.$ for $\left.24 \mathrm{~h}\right)$ before reading. Each strain was tested at antiseptic strengths of $10 \%, 80 \%$ and $90 \%$ with contact times of $5 \mathrm{~min}, 30 \mathrm{~min}$ and $24 \mathrm{~h}$. The efficacy of the compound (1) formulation in situ was evaluated using the hand-washing test with Escherichia coli ATCC 10536 with and without friction, according to standard EN 1499. After washing with soap, fingertips were immersed in the microbial suspension for 5 seconds, allowed to dry for 5 minutes, then rubbed with $1 \mathrm{~mL}$ of antiseptic for 60 seconds and dipped in LB, which was serially diluted immediately. One $\mathrm{mL}$ of each dilution was filtered and the filter was washed with sterile distilled water to remove active substances, followed by incubation of the filter $\left(37^{\circ} \mathrm{C}\right.$ for $\left.24 \mathrm{~h}\right)$ and then reading. 
The cocamidopropyl betaine, edetic acid and coprah diethanolamide formulation devoid of compound (1) was also tested in place of the mild soap required by EN 1499.

\subsection{Statistical analyses}

The distribution of the percentages of bacteria did not significantly deviate from normality. Data were subjected to ANOVA using the GLM procedure of SAS (SAS Institute, 2003) and compared with the 2-tailed Student's t test. P-values $<0.05$ were considered significant. Error bars denote the SD, unless otherwise stated.

\section{Results and discussion}

\subsection{Antimicrobial activity of compound (1)}

Compound (1) is a synthetic ferrocene analogue of tamoxifen with a broad spectrum of action (Table 1). ${ }^{10,11}$ It was found much more potent than doxycycline against Candida albicans ATCC 10231, inhibiting the fungus completely at $3.97 \mu \mathrm{M}$ versus $254 \mu \mathrm{M}$ (Figure 2 ). The nominal $\mathrm{IC}_{50}$ values for these compounds are respectively $5 \mu \mathrm{M}$ and $200 \mu \mathrm{M}$. Doxycycline is a tetracycline derivative with improved pharmacokinetic properties that prevents docking of acylated tRNA to the ribosome, thereby inhibiting translation. ${ }^{16}$ Compound (1) has been shown to alter bacterial membrane structure, causing significant efflux of $\mathrm{K}^{+}$and $\mathrm{Na}^{+}$and ultimately cell death. ${ }^{11}$ This mode of action, combined with low hemolytic activity, makes this substituted diaryl butane attractive for development as an antiseptic. The efficacy of compound (1) at different concentrations was also evaluated in the absence or presence of bovine serum albumin $\left(3 \mathrm{~g} \mathrm{~L}^{-1}\right)$ mimicking unclean surfaces (Table 2). All tested microorganisms were inhibited by 5, 30 min or 24 h of contact at strengths of $80 \%$ and $90 \%$, regardless of the presence of interfering substances. No significant differences found between microbial counts in absence or presence of interfering substances at strengths of 80 and $90 \%$. Nevertheless, at lower strength of compound (1) (10\%) 
required time for efficient action was delayed in presence of interfering substances. For example, 30 min of contact time were necessary at strength of $10 \%$ for effective killing of Pseudomonas aeruginosa in presence of BSA, while five minutes were sufficient in clean conditions. Compound (1) at $80 \%$ strength exhibited antiseptic properties meeting the requirements of standard EN 13727 (5 log reduction in microbial count) in the absence of interfering substances and was only slightly less effective in its presence.

\subsection{Efficacy of the antiseptic formulation}

The compound (1) formulation contained the same surface-active compound (cocamidopropyl betaine), complexing agent (edetic acid) and foam-stabilizing agent (diethanolamide of coprah) as the commercial product $\mathrm{Cyteal}^{\circledR}$. Figure 3 shows the potency of the formulation [concentration of $(\mathbf{1})=300 \mu \mathrm{g} \mathrm{mL}^{-1}$ ] against Staphylococcus aureus ATCC 6538 compared to compound (1) alone and to the commercial product. The formulation appeared as inhibitory as Cytéal ${ }^{\circledR}$, and more inhibitory than compound (1) alone. Table 3 shows the reductions of the counts of the five microbes exposed to different strengths of our formulation or Cytéal ${ }^{\circledR}$ in the absence or presence of interfering substances. In general, compound (1) formulation at strength of $90 \%$ was efficient as Cytéal ${ }^{\circledR}$ at $80 \%$. For example, Escherichia coli reduction of about 7 log cycles after contact for 30 min with compound (1) formulation and Cytéal ${ }^{\circledR}$ were obtained with strengths of $90 \%$ and $80 \%$, respectively. Nevertheless, the two products appeared equally effective as disinfectants, regardless of possible interference from the protein, even though our formulation contained much less active ingredient $\left(300 \mathrm{mg} \mathrm{L}^{-1}\right.$ ). The active ingredients in Cytéal ${ }^{\circledR}$ (Table 1) are hexamidine diisethionate $\left(2,500 \mathrm{mg} \mathrm{L}^{-1}\right)$, chlorhexidine digluconate $\left(12,882.5 \mathrm{mg} \mathrm{L}^{-1}\right)$ and p-chlorocresol $\left(7,500 \mathrm{mg} \mathrm{L}^{-1}\right)$. 
The antiseptic effect of our formulation was then assessed against a clinical isolate of Acinetobacter baumannii in the presence of interfering substance (Table 4). Although $24 \mathrm{~h}$ of incubation were required to kill this resistant germ, this is nevertheless interesting in view of the known resistance of $A$. baumannii to antibiotics and antiseptics. ${ }^{17}$ In phase $2 /$ step 2 , our formulation was tested using the hand-washing test with Escherichia coli ATCC 10536 as a measure of efficacy in situ (standard EN 1499). As shown in Figure 4, 60 seconds of contact were sufficient to reduce significantly $E$. coli counts by 4 log cycles, which meets the standard. The hands of healthcare personnel are common vehicles of HAI transmission, and hygiene is the first line of defense against the risk of propagating infectious microbes. ${ }^{18}$ On the basis of these results, our formulation has potential for application as a disinfectant/antiseptic.

\section{Conclusions}

A novel derivative of tamoxifen (1) was found to be a potent inhibitor of pathogens known to cause HAIs, in accordance with European standards EN 1040 and EN 13727. The formulation met the phase 1 criterion for antiseptics of reducing microbial contaminant counts by $5 \log$ cycles. It also met the phase $2 /$ step 1 criterion of efficacy in the presence of interfering substances, using these microorganisms and a clinical isolate of Acinetobacter baumannii highly resistant to antibiotics and antiseptics. Phase 2/step 2 tests confirmed the capacity of the formulation to reduce E. coli ATCC 10536 counts by 4 log cycles in 60 seconds on human hands. Our formulation containing the novel ferrocenyl diaryl butane citrate compound is therefore a potent biocide, and the present demonstration could lead to the development of a new commercial antiseptic. 


\section{Acknowledgments}

This work was supported by the Ministry of Higher Education and Scientific Research and

Technology of Tunisia and Agence Nationale de la Recherche de France. Authors wish to thank Hanen Ben Hassen for assistance with statistical analyses and Stephen Davids for proofreading the manuscript.

\section{References}

1. S. S. Magill, J. R. Edwards, W. Bamberg, Z. G. Beldavs, G. Dumyati, M. A. Kainer, R. Lynfield, M. Maloney, L. McAllister-Hollod, J. Nadle, S. M. Ray, D. L. Thompson, L. E. Wilson and S. K. Fridkin, New England Journal of Medicine, 2014, 370, 1198-1208.

2. P. Zarb, B. Coignard, J. Griskeviciene, A. Muller, V. Vankerckhoven, K. Weist, M. Goossens, S. Vaerenberg, S. Hopkins, B. Catry, D. Monnet, H. Goossens and C. Suetens, Euro surveillance : bulletin Europeen sur les maladies transmissibles $=$ European communicable disease bulletin, 2012, 17.

3. European Centre for Disease Prevention and Control, Annual epidemiological report 2014 - Antimicrobial resistance and healthcare-associated infections, ECDC, Stockholm, 2015.

4. I. Gargouri, S. Fantoni, M. L. Masmoudi, R. Gharbi and P. Frimat, Rev Fr Allergol Immunol Clin, 2002, 42, 178-192.

5. C. Verdum-Esquer, P. Brochard, G. Ducombs and M. Geniaux, Arch Mal Prof, 2000, 61, 588-596.

6. D. Thiveaud, A. M. Grimoud, N. Marty, C. Roques, J. P. Lodter and G. Chabanon, EMC Odontologie, 2005, 1, 307-339.

7. M. Patra, G. Gasser and N. Metzler-Nolte, Dalton Trans, 2012, 41, 6350-6358.

8. C. Biot and D. Dive, in Medicinal Organometallic Chemistry, eds. G. Jaouen and N. Metzler-Nolte, Springer Berlin Heidelberg, Berlin, Heidelberg2010, pp. 155-193.

9. A. C. de Oliveira, E. A. Hillard, P. Pigeon, D. D. Rocha, F. A. Rodrigues, R. C. Montenegro, L. V. Costa-Lotufo, M. O. Goulart and G. Jaouen, European journal of medicinal chemistry, 2011, 46, 3778-3787.

10. M. El Arbi, P. Pigeon, S. Top, A. Rhouma, S. Aifa, A. Rebai, A. Vessières, M.-A. Plamont and G. Jaouen, Journal of Organometallic Chemistry, 2011, 696, 1038-1048. 
11. M. El Arbi, J. Théolier, P. Pigeon, K. Jellali, F. Trigui, S. Top, S. Aifa, I. Fliss, G. Jaouen and R. Hammami, European journal of medicinal chemistry, 2014, 76, 408-413.

12. R. Hammami, A. Zouhir, J. Ben Hamida, M. Neffati, G. Vergoten, K. Naghmouchi and I. Fliss, Pharm Biol, 2009, 47, 452-457.

13. M. R. Mallaret, D. Luu Duc, G. Manquat and M. Berthieux, Médecine et Maladies Infectieuses, 1997, 27, 827-832.

14. J.-C. Chapalain and J.-M. Puyhardy, Revue Francaise des Laboratoires, 1997, 1997, 6975.

15. S. Messager, K. Hammer, C. Carson and T. Riley, Journal of Hospital Infection, 2005, 59, 220-228.

16. I. Chopra and M. Roberts, Microbiology and molecular biology reviews : MMBR, 2001, 65, 232-260 ; second page, table of contents.

17. E. Martro, A. Hernandez, J. Ariza, M. A. Dominguez, L. Matas, M. J. Argerich, R. Martin and V. Ausina, J Hosp Infect, 2003, 55, 39-46.

18. u. Vesna, in Disinfection and Decontamination, CRC Press2007. 


\section{Figure legends}

Figure 1. Molecular structure of compound (1) (1,1-bis[4-(3-dimethylaminopropoxy)phenyl]-2ferrocenyl-but-1-ene citrate)

Figure 2. Inhibition of the growth of Candida albicans ATCC 10231 in the presence of increasing concentrations of compound (1) (circle) and doxycycline (square)

Figure 3. Inhibition of the growth of Staphylococcus aureus ATCC 6538 by compound (1) alone (a), Cytéal ${ }^{\circledR}$ (b), and the compound (1) formulation (c), all at an active ingredient concentration of $300 \mu \mathrm{g} \mathrm{mL}^{-1}$

Figure 4. Assessment of the antiseptic efficacy of the compound (1) formulation using the handwashing test (standard EN 1499) with Escherichia coli ATCC 10536 (phase 2/step 2) 
Table 1. Composition of the active ingredients in our formulation and commercial antiseptic product Cytéal ${ }^{\circledR}$

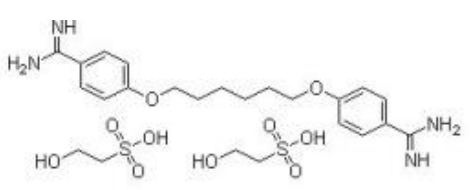

$2,500.0$

(2) Hexamidine diisethionate

Cytéal $^{\circledR}$

(3)

(3) Chlorhexidine digluconate

(4) p-Chlorocresol


Table 2: Antiseptic efficacy of compound (1) against HAI-associated microbes in the presence or absence of interfering substances

\begin{tabular}{|c|c|c|c|c|c|c|c|c|c|c|c|c|c|c|c|c|c|c|c|c|}
\hline \multirow{3}{*}{$\stackrel{\mathscr{E}}{\tilde{E}}$} & \multirow{3}{*}{ 害 } & \multirow{3}{*}{$\begin{array}{c}{[\mathrm{C}]} \\
\text { Tim } \\
\mathrm{e} \\
\end{array}$} & \multicolumn{9}{|c|}{ With interfering substances } & \multicolumn{9}{|c|}{ Without interfering substances } \\
\hline & & & \multicolumn{3}{|c|}{$\mathbf{9 0 \%}$} & \multicolumn{3}{|c|}{$80 \%$} & \multicolumn{3}{|c|}{$10 \%$} & \multicolumn{3}{|c|}{$\mathbf{9 0 \%}$} & \multicolumn{3}{|c|}{$80 \%$} & \multicolumn{3}{|c|}{$10 \%$} \\
\hline & & & $5 \min$ & $30 \mathrm{~min}$ & $24 \mathrm{~h}$ & $5 \min$ & $\begin{array}{c}30 \\
\text { min } \\
\end{array}$ & $24 \mathrm{~h}$ & $5 \mathrm{~min}$ & $\begin{array}{c}30 \\
\text { min } \\
\end{array}$ & $24 \mathrm{~h}$ & $5 \mathrm{~min}$ & $30 \mathrm{~min}$ & $24 \mathrm{~h}$ & $5 \mathrm{~min}$ & $30 \mathrm{~min}$ & $24 \mathrm{~h}$ & $5 \min$ & $30 \mathrm{~min}$ & $24 \mathrm{~h}$ \\
\hline \multirow{2}{*}{ 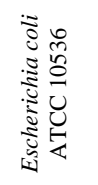 } & \multirow{2}{*}{ 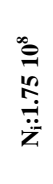 } & $\mathrm{N}_{\mathrm{a}}$ & 58 & 0 & 0 & $\begin{array}{l}>3 \\
10^{2}\end{array}$ & 200 & 150 & $\begin{array}{l}>3 \\
10^{2}\end{array}$ & $\begin{array}{l}>3 \\
10^{2}\end{array}$ & $\begin{array}{l}>3 \\
10^{2}\end{array}$ & 4 & 3 & 0 & 46 & 9 & 0 & $\begin{array}{l}>3 \\
10^{2}\end{array}$ & $\begin{array}{l}>3 \\
10^{2}\end{array}$ & 0 \\
\hline & & $\mathrm{R}$ & $310^{6}$ & $\begin{array}{c}1.75 \\
10^{8}\end{array}$ & $\begin{array}{c}1.75 \\
10^{8}\end{array}$ & - & $\begin{array}{l}8.7 \\
10^{4}\end{array}$ & $\begin{array}{c}1.16 \\
10^{5}\end{array}$ & - & - & - & $\begin{array}{l}4.4 \\
10^{6}\end{array}$ & $\begin{array}{l}5.8 \\
10^{6}\end{array}$ & $\begin{array}{c}1.75 \\
10^{8}\end{array}$ & $\begin{array}{l}3.8 \\
10^{5}\end{array}$ & $\begin{array}{l}1.9 \\
10^{6}\end{array}$ & $\begin{array}{r}1.75 \\
10^{8}\end{array}$ & - & - & $\begin{array}{c}1.75 \\
10^{8}\end{array}$ \\
\hline \multirow{2}{*}{ 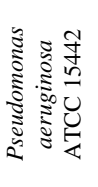 } & \multirow{2}{*}{ 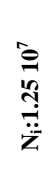 } & $\mathrm{N}_{\mathrm{a}}$ & 0 & 0 & 0 & 0 & 0 & 0 & $\begin{array}{l}>3 \\
10^{2}\end{array}$ & 0 & 0 & 0 & 0 & 0 & 0 & 0 & 0 & 0 & 0 & 0 \\
\hline & & $\mathrm{R}$ & $\begin{array}{l}1.25 \\
10^{7}\end{array}$ & $\begin{array}{c}1.25 \\
10^{7}\end{array}$ & $\begin{array}{c}1.25 \\
10^{7}\end{array}$ & $\begin{array}{c}1.25 \\
10^{7}\end{array}$ & $\begin{array}{r}1.25 \\
10^{7}\end{array}$ & $\begin{array}{c}1.25 \\
10^{7}\end{array}$ & - & $\begin{array}{c}1.25 \\
10^{7}\end{array}$ & $\begin{array}{c}1.25 \\
10^{7}\end{array}$ & $\begin{array}{c}1.25 \\
10^{7}\end{array}$ & $\begin{array}{c}1.25 \\
10^{7}\end{array}$ & $\begin{array}{l}1.25 \\
10^{7}\end{array}$ & $\begin{array}{c}1.25 \\
10^{7}\end{array}$ & $\begin{array}{c}1.25 \\
10^{7}\end{array}$ & $\begin{array}{r}1.25 \\
10^{7}\end{array}$ & $\begin{array}{l}1.25 \\
10^{7}\end{array}$ & $\begin{array}{l}1.25 \\
10^{7}\end{array}$ & $\begin{array}{c}1.25 \\
10^{7}\end{array}$ \\
\hline \multirow{2}{*}{ 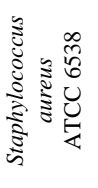 } & \multirow{2}{*}{ 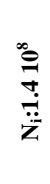 } & $\mathrm{N}_{\mathrm{a}}$ & 10 & 2 & 0 & $\begin{array}{l}>3 \\
10^{2}\end{array}$ & 180 & 80 & $\begin{array}{l}>3 \\
10^{2}\end{array}$ & $\begin{array}{l}>3 \\
10^{2}\end{array}$ & $\begin{array}{l}>3 \\
10^{2}\end{array}$ & 2 & 1 & 0 & 65 & 3 & 0 & $\begin{array}{l}>3 \\
10^{2}\end{array}$ & $\begin{array}{l}>3 \\
10^{2}\end{array}$ & $\begin{array}{l}>3 \\
10^{2}\end{array}$ \\
\hline & & $\mathrm{R}$ & $\begin{array}{l}1.4 \\
10^{6}\end{array}$ & $\begin{array}{c}7 \\
10^{7}\end{array}$ & $\begin{array}{l}1.4 \\
10^{8}\end{array}$ & - & $\begin{array}{c}7 \\
10^{4}\end{array}$ & $\begin{array}{l}1.7 \\
10^{5}\end{array}$ & - & - & - & $\begin{array}{c}7 \\
10^{6}\end{array}$ & $\begin{array}{l}1.4 \\
10^{7}\end{array}$ & $\begin{array}{l}1.4 \\
10^{8}\end{array}$ & $\begin{array}{c}2 \\
10^{5}\end{array}$ & $\begin{array}{l}4.6 \\
10^{6}\end{array}$ & $\begin{array}{l}1.4 \\
10^{8}\end{array}$ & - & - & - \\
\hline \multirow{2}{*}{ 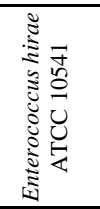 } & \multirow{2}{*}{ 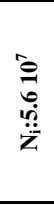 } & $\mathrm{N}_{\mathrm{a}}$ & 0 & 0 & 0 & 0 & 0 & 0 & 20 & 0 & 0 & 0 & 0 & 0 & 0 & 0 & 0 & 0 & 0 & 0 \\
\hline & & $\mathrm{R}$ & $\begin{array}{l}5.6 \\
10^{7}\end{array}$ & $\begin{array}{l}5.6 \\
10^{7}\end{array}$ & $\begin{array}{l}5.6 \\
10^{7}\end{array}$ & $\begin{array}{l}5.6 \\
10^{7}\end{array}$ & $\begin{array}{l}5.6 \\
10^{7}\end{array}$ & $\begin{array}{l}5.6 \\
10^{7}\end{array}$ & $\begin{array}{l}2.8 \\
10^{5}\end{array}$ & $\begin{array}{l}5.6 \\
10^{7}\end{array}$ & $\begin{array}{l}5.6 \\
10^{7}\end{array}$ & $\begin{array}{l}5.6 \\
10^{7}\end{array}$ & $\begin{array}{l}5.6 \\
10^{7}\end{array}$ & $\begin{array}{l}5.6 \\
10^{7}\end{array}$ & $\begin{array}{l}5.6 \\
10^{7}\end{array}$ & $\begin{array}{l}5.6 \\
10^{7}\end{array}$ & $\begin{array}{l}5.6 \\
10^{7}\end{array}$ & $\begin{array}{l}5.6 \\
10^{7}\end{array}$ & $\begin{array}{l}5.6 \\
10^{7}\end{array}$ & $\begin{array}{l}5.6 \\
10^{7}\end{array}$ \\
\hline \multirow{2}{*}{ 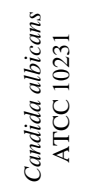 } & \multirow{2}{*}{$\frac{\hat{g}}{\ddot{\ddot{z}}}$} & $\mathrm{~N}_{\mathrm{a}}$ & 0 & 0 & 0 & $\begin{array}{l}1.8 \\
10^{2}\end{array}$ & 0 & 0 & $\begin{array}{l}>3 \\
10^{2}\end{array}$ & $\begin{array}{l}>3 \\
10^{2}\end{array}$ & $\begin{array}{l}>3 \\
10^{2}\end{array}$ & 0 & 1 & 1 & $\begin{array}{l}>3 \\
10^{2}\end{array}$ & 100 & 0 & $\begin{array}{l}>3 \\
10^{2}\end{array}$ & $\begin{array}{l}>3 \\
10^{2}\end{array}$ & 1 \\
\hline & & $\mathrm{R}$ & $\begin{array}{c}7 \\
10^{6}\end{array}$ & $\begin{array}{c}7 \\
10^{6}\end{array}$ & $\begin{array}{c}7 \\
10^{6}\end{array}$ & $\begin{array}{l}3.8 \\
10^{4}\end{array}$ & $\begin{array}{c}7 \\
10^{6}\end{array}$ & $\begin{array}{c}7 \\
10^{6}\end{array}$ & - & - & - & $\begin{array}{c}7 \\
10^{6}\end{array}$ & $\begin{array}{c}7 \\
10^{6}\end{array}$ & $\begin{array}{c}7 \\
10^{6}\end{array}$ & $\begin{array}{c}23 \\
10^{1}\end{array}$ & $\begin{array}{c}7 \\
10^{4}\end{array}$ & $\begin{array}{c}7 \\
10^{6}\end{array}$ & - & - & $\begin{array}{c}7 \\
10^{6}\end{array}$ \\
\hline
\end{tabular}

$\mathrm{N}_{\mathrm{i}}$ : Initial contamination; $\mathrm{N}_{\mathrm{a}}$ : Contamination after treatment; $\mathrm{R}$ : Reduction 
Table 3: Antiseptic efficacy of the compound (1) formulation and Cytéal ${ }^{\circledR}$ in the presence of interfering substances

\begin{tabular}{|c|c|c|c|c|c|c|c|c|c|c|c|c|c|c|c|c|c|c|c|c|}
\hline \multirow{3}{*}{ 量 } & \multirow{3}{*}{ 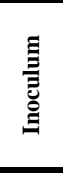 } & \multirow{3}{*}{$\begin{array}{c}{[\mathrm{C}]} \\
\text { Tim } \\
\mathrm{e} \\
\end{array}$} & \multicolumn{9}{|c|}{ Compound (1) formulation } & \multicolumn{9}{|c|}{ Cytéal $^{\circledR}$} \\
\hline & & & \multicolumn{3}{|c|}{$90 \%$} & \multicolumn{3}{|c|}{$80 \%$} & \multicolumn{3}{|c|}{$10 \%$} & \multicolumn{3}{|c|}{$90 \%$} & \multicolumn{3}{|c|}{$\mathbf{8 0 \%}$} & \multicolumn{3}{|c|}{$10 \%$} \\
\hline & & & $5 \min$ & $30 \mathrm{~min}$ & $24 \mathrm{~h}$ & $5 \min$ & $\begin{array}{c}30 \\
\mathrm{~min} \\
\end{array}$ & $24 \mathrm{~h}$ & $5 \mathrm{~min}$ & $\begin{array}{c}30 \\
\text { min } \\
\end{array}$ & $24 \mathrm{~h}$ & $5 \mathrm{~min}$ & $30 \mathrm{~min}$ & $24 \mathrm{~h}$ & $5 \min$ & $30 \mathrm{~min}$ & $24 \mathrm{~h}$ & $5 \min$ & $30 \min$ & $24 \mathrm{~h}$ \\
\hline \multirow{2}{*}{ 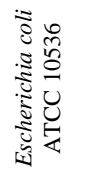 } & \multirow{2}{*}{ 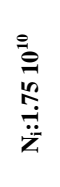 } & $\mathrm{N}_{\mathrm{a}}$ & $>310^{2}$ & 240 & 0 & $>310^{2}$ & $>310^{2}$ & $>310^{2}$ & $\begin{array}{l}>3 \\
10^{2}\end{array}$ & $>310^{2}$ & $>310^{2}$ & $>310^{2}$ & 200 & 0 & $>310^{2}$ & 167 & 0 & $>310^{2}$ & $>310^{2}$ & $>310^{2}$ \\
\hline & & $\mathrm{R}$ & - & $7.310^{6}$ & $\begin{array}{l}1.75 \\
10^{10}\end{array}$ & - & - & - & - & - & - & - & $8.710^{6}$ & $\begin{array}{l}1.75 \\
10^{10}\end{array}$ & - & $\begin{array}{l}1.04 \\
10^{7}\end{array}$ & $\begin{array}{l}1.75 \\
10^{10}\end{array}$ & - & - & - \\
\hline \multirow{2}{*}{ 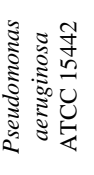 } & \multirow{2}{*}{ 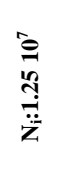 } & $\mathrm{N}_{\mathrm{a}}$ & 3 & 0 & 0 & 51 & 2 & 0 & $\begin{array}{l}>3 \\
10^{2}\end{array}$ & 79 & 56 & - & - & - & - & - & - & - & - & - \\
\hline & & $\mathrm{R}$ & $\begin{array}{l}4.1 \\
10^{5}\end{array}$ & $\begin{array}{l}1.25 \\
10^{7}\end{array}$ & $1.2510^{7}$ & $\begin{array}{l}2.5 \\
10^{4}\end{array}$ & $\begin{array}{l}6.2 \\
10^{5}\end{array}$ & $\begin{array}{l}1.25 \\
10^{7}\end{array}$ & - & $\begin{array}{l}1.6 \\
10^{4}\end{array}$ & $2.210^{4}$ & - & - & - & - & - & - & - & - & - \\
\hline \multirow{2}{*}{ 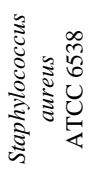 } & \multirow{2}{*}{ 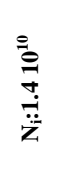 } & $\mathrm{N}_{\mathrm{a}}$ & 250 & 240 & 0 & $>310^{2}$ & $>310^{2}$ & $>310^{2}$ & $\begin{array}{l}>3 \\
10^{2}\end{array}$ & $>310^{2}$ & $>310^{2}$ & 69 & 0 & 0 & 112 & 140 & 2 & $>310^{2}$ & $>310^{2}$ & 40 \\
\hline & & $\mathrm{R}$ & $\begin{array}{l}5.6 \\
10^{6}\end{array}$ & $5.810^{6}$ & $1.410^{10}$ & - & - & - & - & - & - & $\begin{array}{c}2 \\
10^{7}\end{array}$ & $\begin{array}{c}1.4 \\
10^{10}\end{array}$ & $1.410^{10}$ & $\begin{array}{l}1.25 \\
10^{7}\end{array}$ & $\begin{array}{c}1 \\
10^{7}\end{array}$ & $\begin{array}{c}7 \\
10^{8}\end{array}$ & - & - & $\begin{array}{l}3.5 \\
10^{7}\end{array}$ \\
\hline \multirow{2}{*}{ 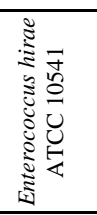 } & \multirow{2}{*}{$\begin{array}{l}\hat{o} \\
b \\
\dot{g} \\
\ddot{z}\end{array}$} & $\mathrm{~N}_{\mathrm{a}}$ & 1 & 2 & 0 & $>310^{2}$ & 20 & 4 & $\begin{array}{l}>3 \\
10^{2}\end{array}$ & 16 & 11 & - & - & - & - & - & - & - & - & - \\
\hline & & $\mathrm{R}$ & $\begin{array}{l}5.6 \\
10^{6}\end{array}$ & $2.810^{6}$ & $5.610^{7}$ & - & $\begin{array}{l}2.8 \\
10^{5}\end{array}$ & $1.410^{6}$ & - & $\begin{array}{l}3.5 \\
10^{5}\end{array}$ & $5.110^{5}$ & - & - & - & - & - & - & - & - & - \\
\hline \multirow{2}{*}{ 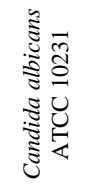 } & \multirow{2}{*}{$\frac{\stackrel{o}{g}}{\dddot{z}}$} & $\mathrm{~N}_{\mathrm{a}}$ & 25 & 29 & 0 & 97 & 50 & 0 & $\begin{array}{l}>3 \\
10^{2}\end{array}$ & 200 & 110 & 80 & 0 & 0 & 98 & 2 & 0 & 200 & 53 & 29 \\
\hline & & $\mathrm{R}$ & $\begin{array}{l}2.8 \\
10^{8}\end{array}$ & $\begin{array}{c}2.41 \\
10^{8}\end{array}$ & $\begin{array}{c}7 \\
10^{10}\end{array}$ & $\begin{array}{l}7.2 \\
10^{7}\end{array}$ & $\begin{array}{l}1.4 \\
10^{8}\end{array}$ & $\begin{array}{c}7 \\
10^{10}\end{array}$ & - & $\begin{array}{l}3.5 \\
10^{7}\end{array}$ & $\begin{array}{c}6.36 \\
10^{7}\end{array}$ & $\begin{array}{l}8.7 \\
10^{7}\end{array}$ & $\begin{array}{c}7 \\
10^{10}\end{array}$ & $\begin{array}{c}7 \\
10^{10}\end{array}$ & $7.110^{7}$ & $3.510^{9}$ & $\begin{array}{c}7 \\
10^{10}\end{array}$ & $\begin{array}{l}3.5 \\
10^{7}\end{array}$ & $\begin{array}{l}1.32 \\
10^{7}\end{array}$ & $\begin{array}{l}2.4 \\
10^{8}\end{array}$ \\
\hline
\end{tabular}

$\mathrm{N}_{\mathrm{i}}$ : Initial contamination; $\mathrm{N}_{\mathrm{a}}$ : Contamination after treatment; $\mathrm{R}$ : Reduction 
Table 4: Antiseptic effect of compound (1) against a clinical isolate of Acinetobacter baumannii in the presence of interfering substances

\begin{tabular}{|c|c|c|c|c|c|c|c|c|c|c|}
\hline \multirow{2}{*}{ Strain and initial count } & \multirow[b]{2}{*}{ Time } & \multicolumn{9}{|c|}{ Formulation strength } \\
\hline & & $5 \min$ & $30 \mathrm{~min}$ & $24 \mathrm{~h}$ & $5 \mathrm{~min}$ & $30 \mathrm{~min}$ & $24 \mathrm{~h}$ & $5 \mathrm{~min}$ & $30 \mathrm{~min}$ & $24 \mathrm{~h}$ \\
\hline \multirow{2}{*}{$\begin{array}{c}\text { Acinetobacter baumannii } \\
\qquad \mathbf{N}_{\mathrm{i}}: \mathbf{6 . 3 9} 10^{\mathbf{8}}\end{array}$} & $\mathrm{N}_{\mathrm{a}}$ & $>310^{2}$ & $>310^{2}$ & 24 & $>310^{2}$ & $>310^{2}$ & $>310^{2}$ & $>310^{2}$ & $>310^{2}$ & $>310^{2}$ \\
\hline & $\mathrm{R}$ & - & - & $2.6610^{6}$ & - & - & - & - & - & - \\
\hline
\end{tabular}




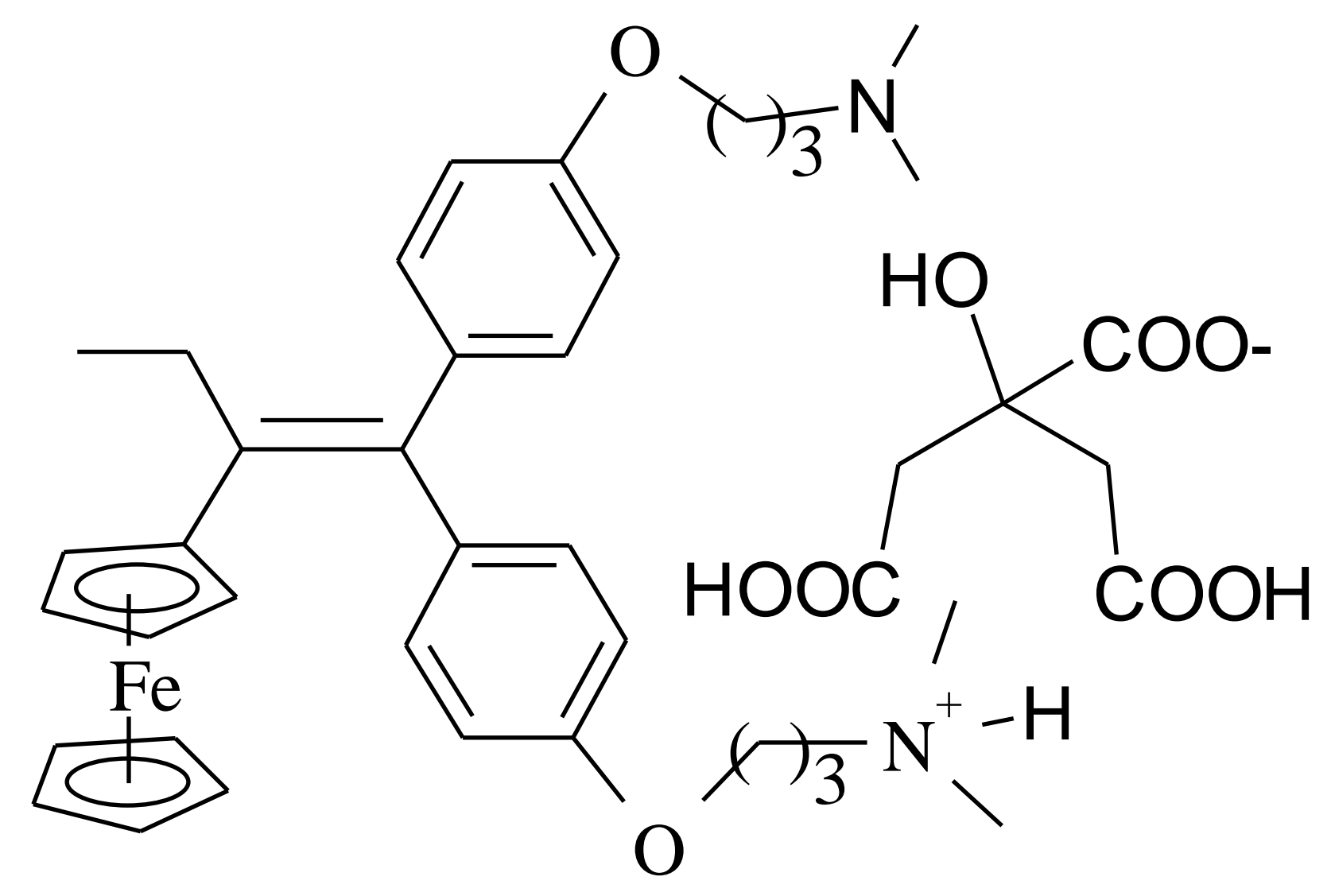

Figure 1. 


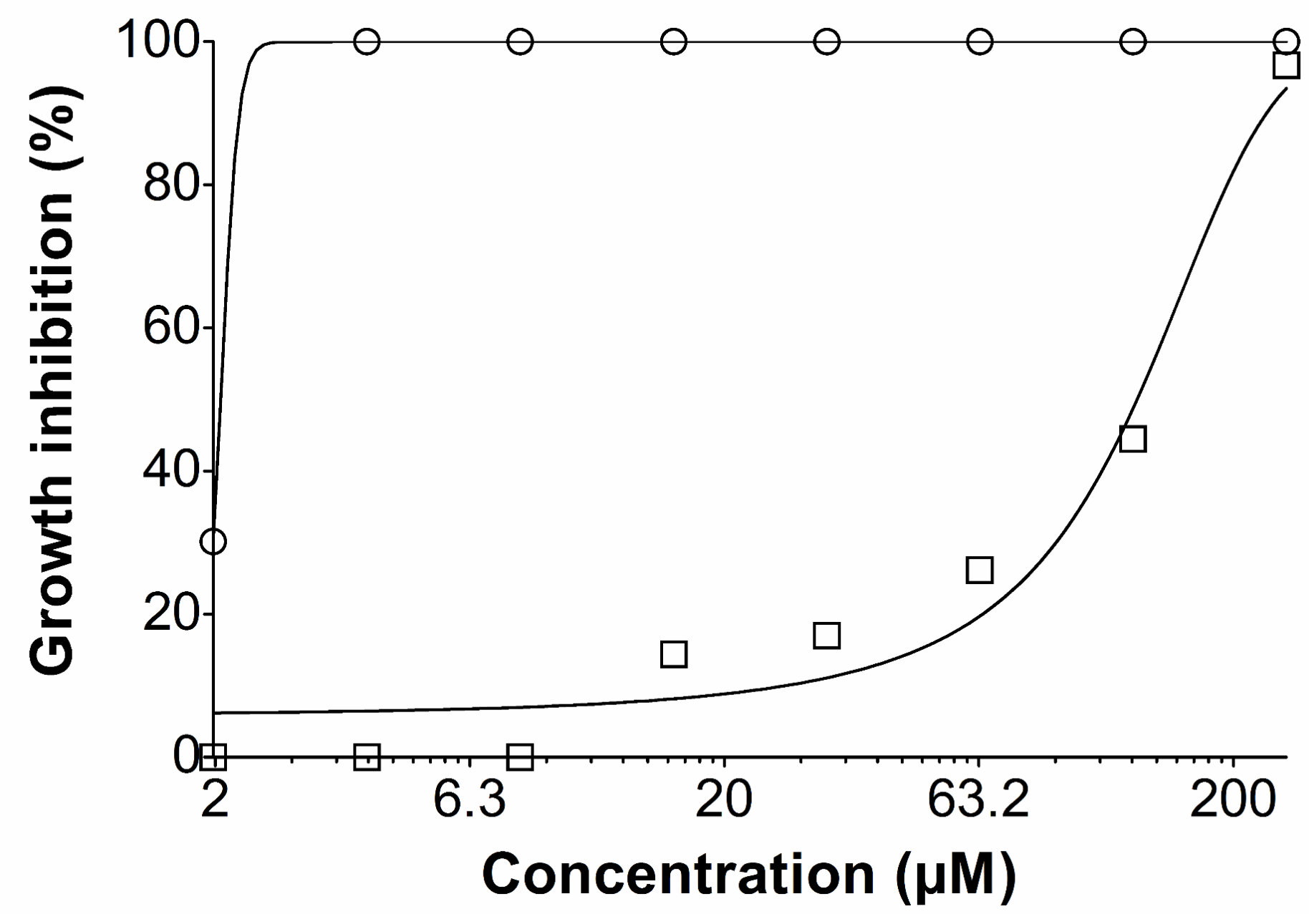

Figure 2. 


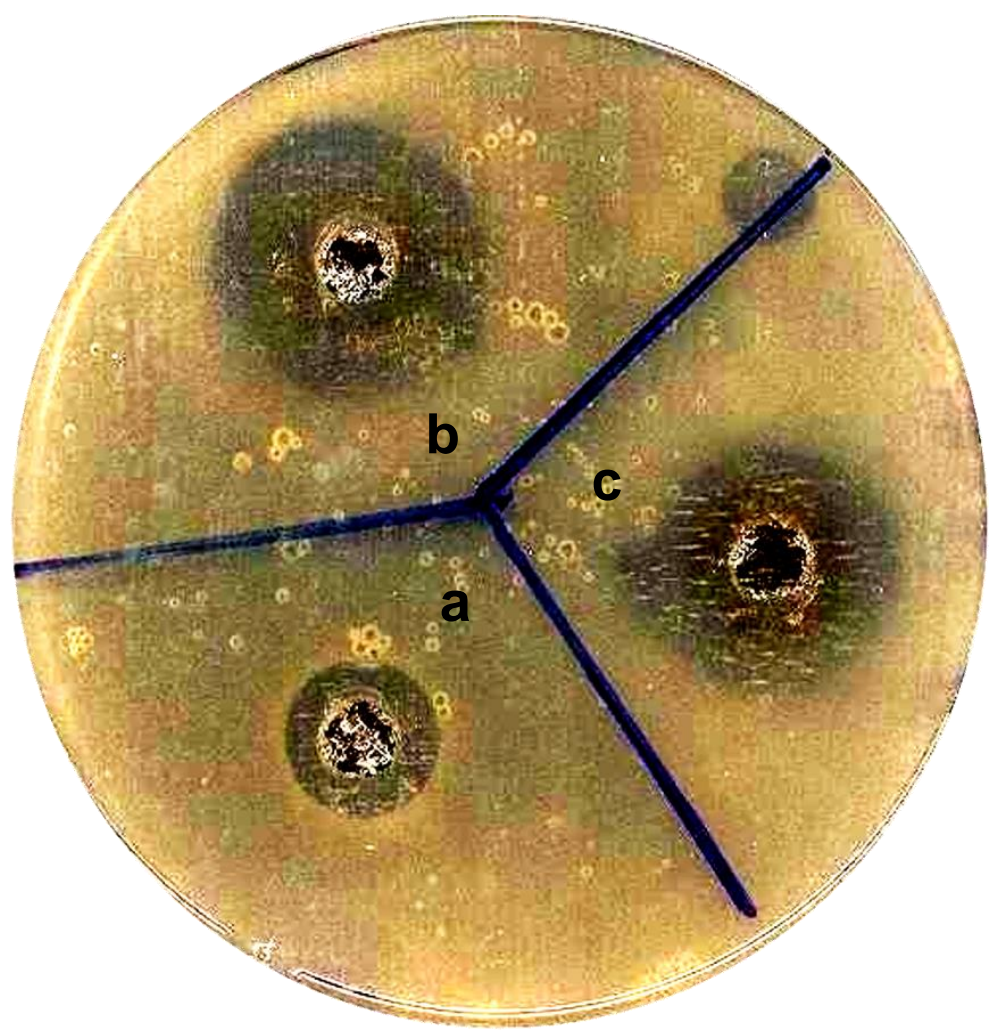

Figure 3. 


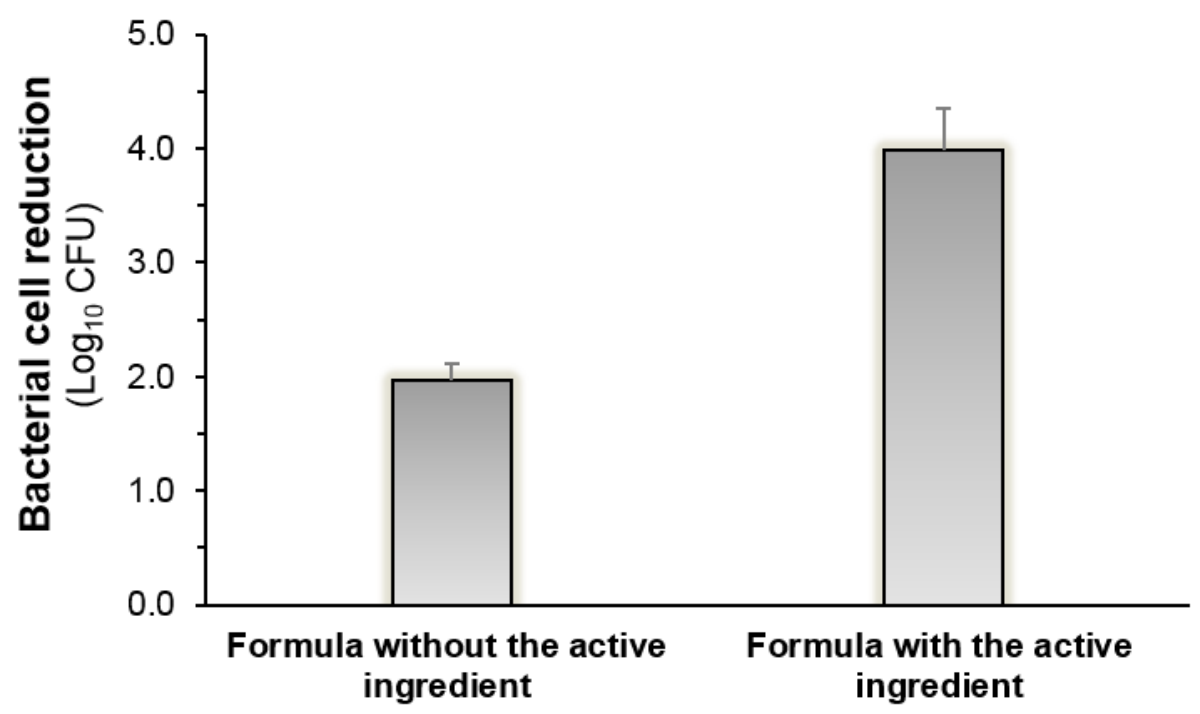

Figure 4. 